\title{
PEMBUATAN AUDIO UNTUK MENGOLAH SINYAL INPUT DARI HANDPHONE
}

\author{
Mohamad Amin \\ Teknik Mesin Politeknik Negeri Balikpapan \\ e-mail: mohamad.amin@poltekba.ac.id
}

\begin{abstract}
Has conducted experiments in the manufacture of audio to process the input signal from the hanphone into a modifier indicator is the intensity of the sound from the speakers. The circuit is essentially changing the mechanical waves into electricity and then changed again to become a mechanic. This transformation using multiple circuits, ie step-down transformer, power supply, tone control, poweramp small class AB power transistor pair BD 139 and BD 140, and speaker. Obtained from an experiment in class AB power amp happen reinforcement 16.67 times. After going through this series, in accordance with the desired signal that changes in volume can be regulated by the sliding barrier which change the value of the current flowing, and then change the intensity of the sound volume is also shown on the changes sound from the speakers when the tone control is rotated to right or left rotated.
\end{abstract}

Keywords: power supply, tone control, power amp small class AB power transistor pair BD 139 and BD 140

\begin{abstract}
Abstrak
Telah dilakukan eksperimen dalam pembuatan audio untuk mengolah sinyal input dari hanphone yang menjadi indicator pengubahannya adalah intensitas bunyi dari speaker. Rangkaian ini pada intinya mengubah gelombang mekanik menjadi listrik kemudian diubah lagi menjadi mekanik. Pengubahan ini menggunakan beberapa rangkaian, yaitu trafo step down, catu daya, tone control, poweramp kelas AB daya kecil dengan pasangan transistor BD 139 dan BD 140, dan speaker. Didapatkan dari percobaan pada power amp kelas AB terjadi penguatan sebesar 16,67 kali. Setelah melalui rangkaian ini, sinyal sesuai dengan yang diinginkan bahwa perubahan volume bisa diatur dengan hambatan geser yang mengubah nilai arus yang mengalir, kemudian perubahan intensitas volume suara juga ditunjukan pada perubahan suara dari speaker pada saat tone control diputar kekanan atu diputar kekiri.
\end{abstract}

Kata Kunci: catu daya, tone control, power amp kelas AB daya kecil dengan pasangan transistor BD 139 dan BD 140

\section{Pendahuluan}

Pendengaran merupakan indra yang sangat penting untuk manusia, karena dengan kemampuan mendengar ini manusia bisa saling bertukar informasi melalui bunyi. Selain sebagai jalan bertukar informasi, bunyi juga sering dipakai untuk hiburan melalui musik. Musik dengan ragam frekuensi dari vokal dan alat musik menghasilkan bunyi tertentu yang bisa didengar sesuai dengan batas pendengaran telinga manusia.

Bunyi merupakan besaran fisika yang dipengaruhi oleh besaran lain seperti amplitudo dan frekuensi yang berbedabeda. Dengan berbagai keperluan yang kita butuhkan, kita perlu mengubah nilai frekuensi dan amplitudo yang dihasilkan oleh sumber bunyi. Bunyi merupakan gelombang mekanik yang bisa diubah variabel-variabel penyusunnya dengan dilewatkan melalui rangkaian elektronik untuk mengubah amplitudo dan frekuensinya.

Melalui rangkaian elektronik ini maka gelombang mekanik diubah menjadi gelombang listrik dan setelah itu ia diubah kembali menjadi gelombang mekanik melalui speaker. hal ini terjadi karena gelombang listrik adalah gelombang yang mudah diubah. 


\section{Teori Dasar}

Pada dasarnya eksperimen ini bertujuan untuk mengolah sinyal input dari sumber bunyi (handphone). Sinyal input dari handphone akan dimasukan ke rangkaian tone control. Sinyal yang berfrekuensi rendah akan diolah oleh rangkaian Low Pass Filter (LPF), sedangkan frekuensi tinggi akan diolah oleh rangkaian High Pass Filter (HPF). Kemudian setelah melalui rangkaian tone control, sinyal ini dikuatkan kembali oleh amplifier yang kemudian dihubungkan dengan speaker.

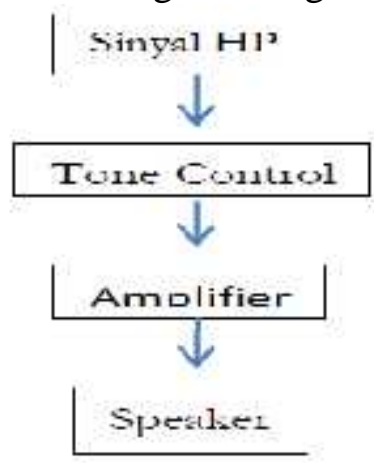

Gambar 1. Alur Perjalanan Sinyal Hp

Adapun penjelasan rangkaian yang digunakan sebagai berikut :

\section{a. Trafo}

Trafo adalah suatu alat listrik yang dapat memindahkan dan mengubah energi listrik dari satu rangngakaian atau lebih kerangkaian listrik yang lain melalui suatu gandengan magnet menggunakan prinsip induksi electromagnet ${ }^{[4]}$. Alat ini berfungsi mengubah tegangan masuk yang akan digunakan kepada rangkaian. Berhubung tegangan sumber tegangan AC dari PLN $220 \mathrm{~V}$, maka trafo yang digunakan adalah trafo $\mathrm{CT}$ step down dengan keluaran tegangan $\mathrm{AC}+18 \mathrm{~V}$.

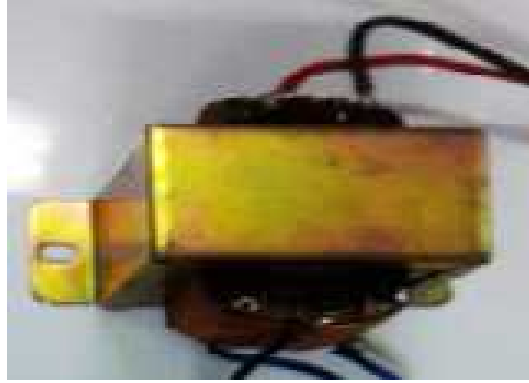

Gambar 2. Trafo CT Step down

\section{b. Catu Daya}

Rangkaian ini berfungsi untuk mengkonversi dan menurunkan tegangan AC dari trafo menjadi tegangan \pm 15 Volt DC dan menstabilkan tegangan yang dihasilkan ${ }^{[5]}$. Rangkaian yang digunakan untuk catu daya sebagai berikut :

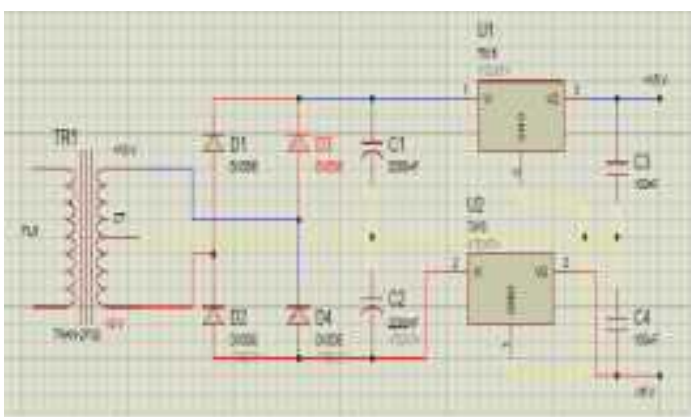

Gambar 3. Desain Rangkaian Catu Daya \pm 15 V

Beberapa kompenen yang digunakan yaitu trafo step down, 4 buah diode, 2 buah kapasitor electrolyte 2200 F, 2 buah kapasitor 100 F, 1 buah IC Regulator 7815, dan 1 buah IC Regulator 7915. er, kapasitor, transistor, dan resistor. Berikut rangkaian yang digunakan dalam percobaan kami:

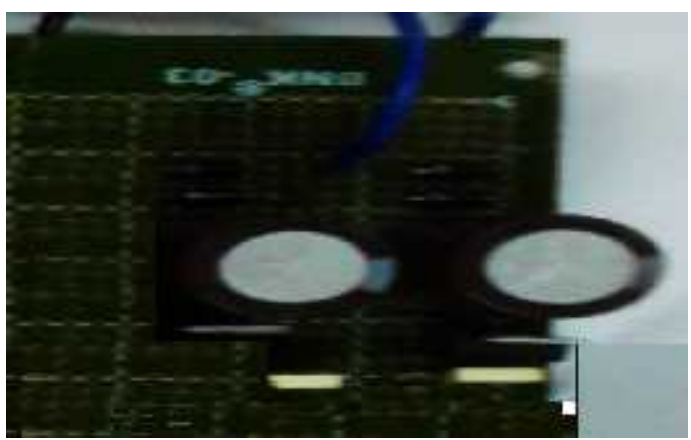

Gambar 4. Rangkaian catu daya pada eksperimen 


\section{c. Tone Control}

Rangkaian ini berfungsi untuk mengatur nilai mid, bass, dan treblenya. Untuk mengatur mid, bass, dan treblenya maka rangkaian yang digunakan adalah rangkaian Low Pass Filter (LPF) dan rangkaian High Pass Filter (HPF).

\section{Low Pass Filter (LPF)}

Filter lolos rendah ini hanya melewatkan frekuensi yang lebih rendah dari frekuensi potong. Diatas frekuensi itu outputnya mengecil (idealnya tidak ada). Rangkaian dan grafik penguatan terhadap log frekuensinya dinyatakan sebagai berikut :

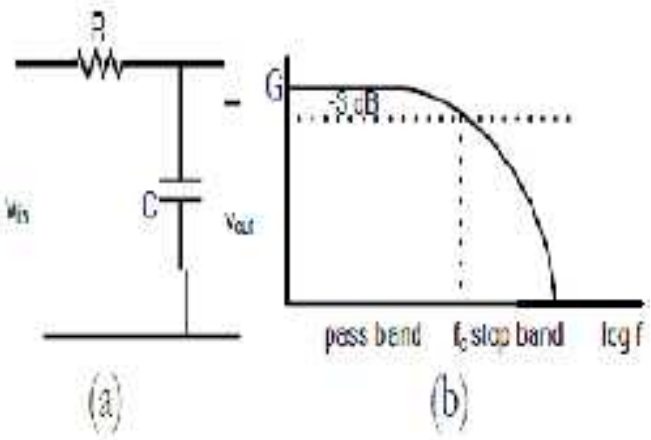

Gambar. 5. a. Rangkaian RC LF pasif, b.tanggapannya ${ }^{[1]}$

Persamaan untuk penguatan dayanya adalah:

$\mathrm{G}=20 \log \frac{V_{O}}{V_{1}} \ldots \ldots \ldots \ldots \ldots$ Pers $.1^{[1]}$

Keterangan :

Vo = tegangan output

$\mathrm{Vi}=$ tegangan input

Penguatan Filternys adalah :

$\mathrm{G}=\frac{1}{1+\frac{f}{f_{c}}{ }^{2}} \ldots \ldots \ldots \ldots$ Pers. $2^{[2]}$

Keterangan :

$\mathrm{f}=$ frekuensi input

$\mathrm{f}=$ frekuensi potong

\section{High Pass Filter (HPF)}

Filter Lolos tinggi melewatkan frekuensi di atas frekuensi potongnya, dibawah frekuensi itu output idealnya tidak ada. Rangkaian RC HPF dan tanggapan frekuensinya ditunjukan pada gambar berikut.

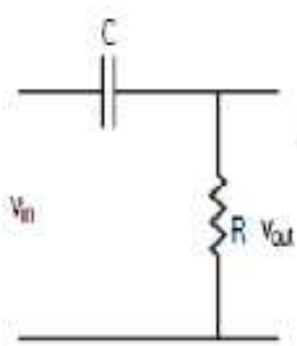

ia

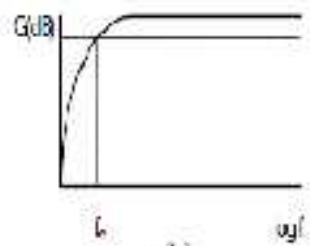

(b)
Gambar 6. (a). Rangkaian HPF pasif (b) tanggapan frekuensinya ${ }^{[1]}$

Persamaan penguatan filternya :

$\mathrm{G}=\frac{\frac{f}{f_{c}}}{1+\frac{f_{-2}}{f_{c}}}$

Pers. $3^{[2]}$

Pada eksperimen kami desain rangkaian tone control sebagai berikut:

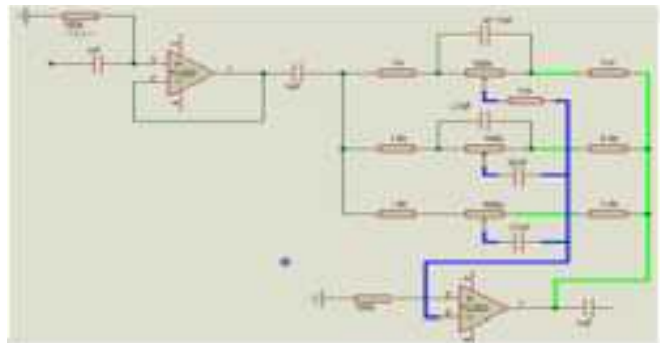

Gambar 7. Desain Rangkaian 3-Band Tone Control dengan Buffer Op-amp IC TL082

Pada eksperimen untuk tone control adalah sebagai berikut:

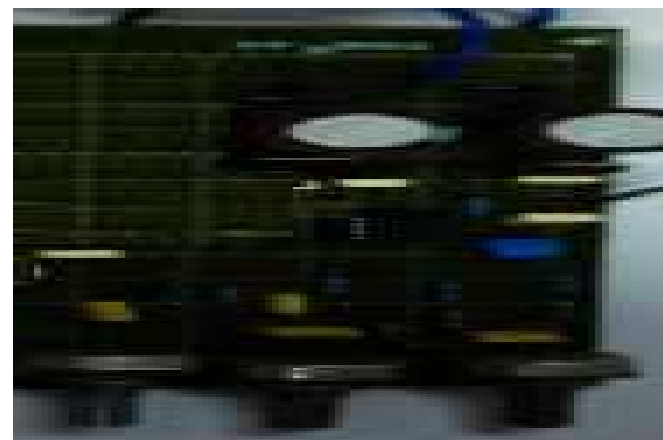

Gambar 8. Rangkaian 3-Band Tone Control dengan Buffer Op-amp IC TL082 


\section{d. Penguat (amplifier)}

Alat ini berfungsi untuk menguatkan sinyal yang telah diolah oleh tone control.

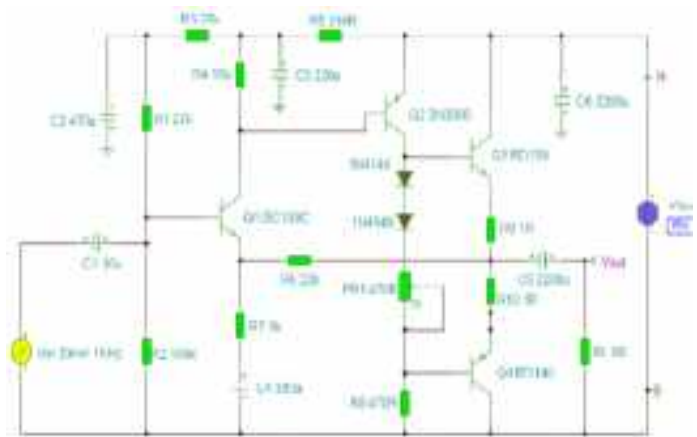

Gambar 9. Desain Rangkaian Amplifier Kelas $\mathrm{AB}$ sederhana ${ }^{[2]}$

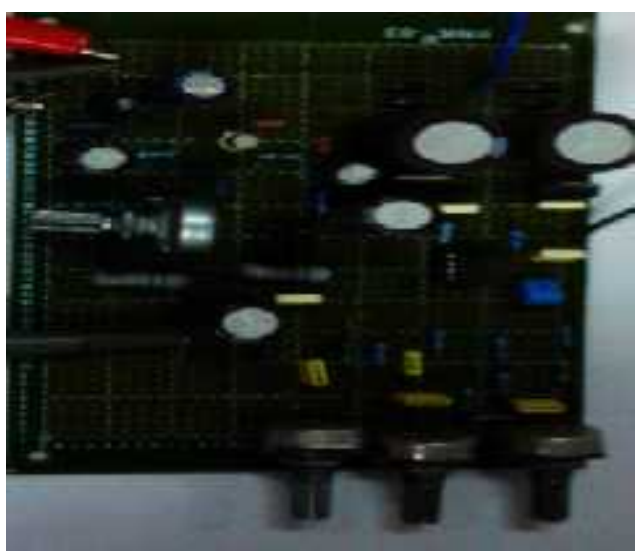

Gambar 10. Rangkaian RBL Audio dengan Rangkaian Amplifier Kelas AB sederhana

\section{e. Speaker}

Alat ini berfungsi untuk menunjukkan hasil pengolahan sinyal oleh tune control dan amplifier.

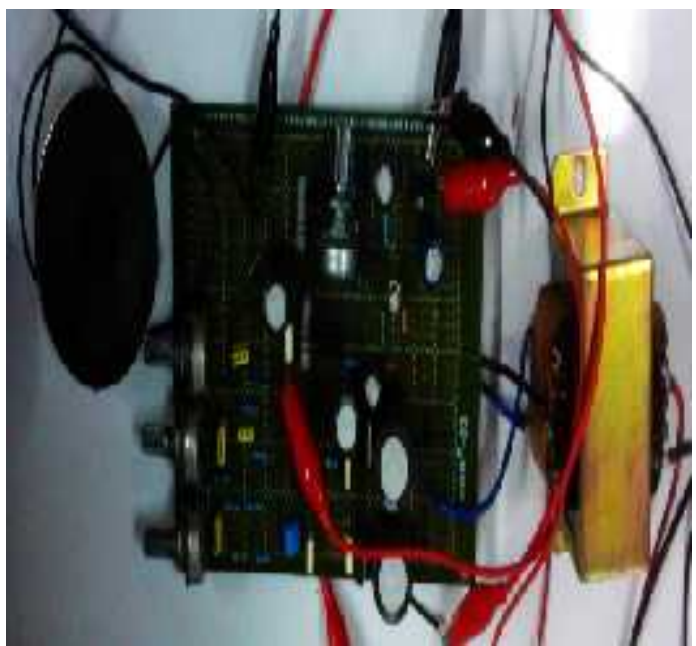

Gambar 11. Rangkaian RBL dengan speaker

\section{Metode Penelitian}

Metode yang digunakan dalam penelitian ini adalah metode eksperimen. Adapun langkah-langkah yang diambil untuk melakukan penelitian ini meliputi persiapan bahan dan alat, perakitan alat, dan melakukan pengujian alat peraga.

\section{Data Hasil Penelitian}

a. Catu Daya (Power Supply)

Pada rangkaian catu daya (Gambar 3) didapatkan data yang disajikan sebagai berikut :

- Tegangan Keluaran Positif $=15 \mathrm{~V}$

- Tegangan Keluaran Negatif $=14,9 \mathrm{~V}$

Tabel 1. Data Pembebanan Rangkaian Penyearah Gelombang Penuh dengan IC

\begin{tabular}{cc}
\hline $\mathrm{RL}(\Omega)$ & Vout (Volt) \\
\hline 909 & 15.02 \\
841 & 15.02 \\
749 & 15.02 \\
655 & 15.02 \\
564 & 15.02 \\
471 & 15.02 \\
382 & 15.02 \\
192.5 & 15.02 \\
96.9 & 15.02 \\
89.9 & 15.02 \\
79.4 & 15.02 \\
69.8 & 14.99 \\
60.8 & 14.97 \\
50.1 & 14.96 \\
40.6 & 14.95 \\
30.4 & 14.94 \\
21.1 & 14.93 \\
11.7 & 14.92 \\
9.5 & 14.92 \\
8.1 & 14.92 \\
7.1 & 14.92 \\
6.5 & 14.91 \\
5.3 & 14.91 \\
4.2 & 14.91 \\
3.1 & 14.91 \\
2.3 & 14.9 \\
1.2 & 14.89 \\
\hline & \\
\hline
\end{tabular}




\section{b. Tone Control}

Data hasil pengukuran tone kontrol untuk 5 kondisi sebagai berikut :

Tabel 2. Kondisi 1 Bass Flat, Mid Flat, dan Trebel Flat

\begin{tabular}{|c|c|c|c|}
\hline $\mathrm{f}(\mathrm{Hz})$ & Vi (V) & Vo (V) & $G(d B)$ \\
\hline 10 & 1 & 1 & 0 \\
\hline 20 & 1 & 1 & 0 \\
\hline 30 & 1 & 1 & 0 \\
\hline 40 & 1 & 1 & 0 \\
\hline 50 & 1 & 1 & 0 \\
\hline 60 & 1 & 1 & 0 \\
\hline 70 & 1 & 1 & 0 \\
\hline 80 & 1 & 1 & 0 \\
\hline 90 & 1 & 1 & 0 \\
\hline 100 & 1 & 1 & 0 \\
\hline 200 & 1 & 1 & 0 \\
\hline 300 & 1 & 1 & 0 \\
\hline 400 & 1 & 1 & 0 \\
\hline 500 & 1 & 1 & 0 \\
\hline 600 & 1 & 1 & 0 \\
\hline 700 & 1 & 1 & 0 \\
\hline 800 & 1 & 1 & 0 \\
\hline 900 & 1 & 1 & 0 \\
\hline 1000 & 1 & 1 & 0 \\
\hline 2000 & 1 & 1 & 0 \\
\hline 3000 & 1 & 1 & 0 \\
\hline 4000 & 1 & 1 & 0 \\
\hline 5000 & 1 & 1 & 0 \\
\hline 6000 & 1 & 1 & 0 \\
\hline 7000 & 1 & 1 & 0 \\
\hline 8000 & 1 & 1 & 0 \\
\hline 9000 & 1 & 1 & 0 \\
\hline 10000 & 1 & 1 & 0 \\
\hline 20000 & 1 & 1 & 0 \\
\hline 30000 & 1 & 1 & 0 \\
\hline 40000 & 1 & 1 & 0 \\
\hline 50000 & 1 & 1 & 0 \\
\hline 60000 & 1 & 1 & 0 \\
\hline 70000 & 1 & 1 & 0 \\
\hline 80000 & 1 & 1 & 0 \\
\hline 90000 & 1 & 1 & 0 \\
\hline 100000 & 1 & 1 & 0 \\
\hline 200000 & 1 & 1 & 0 \\
\hline 300000 & 1 & 1 & 0 \\
\hline 400000 & 1 & 1 & 0 \\
\hline 500000 & 1 & 1 & 0 \\
\hline 600000 & 1 & 1 & 0 \\
\hline 700000 & 1 & 1 & 0 \\
\hline
\end{tabular}

\begin{tabular}{cccc}
800000 & 1 & 1 & 0 \\
900000 & 1 & 1 & 0 \\
1000000 & 1 & 1 & 0 \\
\hline
\end{tabular}

Tabel 3. Kondisi 2 Bass Boost, Mid Flat, dan Trebel Boost

\begin{tabular}{|c|c|c|c|}
\hline $\mathbf{f}(\mathbf{H z})$ & Vi (V) & Vo (V) & $G(d B)$ \\
\hline 10 & 1 & 1,6 & 4,08239965 \\
\hline 20 & 1 & 4,2 & 12,4649858 \\
\hline 30 & 1 & 5,2 & 14,3200669 \\
\hline 40 & 1 & 5 & 13,9794001 \\
\hline 50 & 1 & 4,6 & 13,2551566 \\
\hline 60 & 1 & 4 & 12,0411998 \\
\hline 70 & 1 & 3,8 & 11,5956719 \\
\hline 80 & 1 & 3,4 & 10,6295783 \\
\hline 90 & 1 & 3 & 9,54242509 \\
\hline 100 & 1 & 2,8 & 8,94316063 \\
\hline 200 & 1 & 1,6 & 4,08239965 \\
\hline 300 & 1 & 1,3 & 2,27886705 \\
\hline 400 & 1 & 1,2 & 1,58362492 \\
\hline 500 & 1 & 1,1 & 0,82785370 \\
\hline 600 & 1 & 1,1 & 0,82785370 \\
\hline 700 & 1 & 1,1 & 0,82785370 \\
\hline 800 & 1 & 1,1 & 0,82785370 \\
\hline 900 & 1 & 1,2 & 1,58362492 \\
\hline 1000 & 1 & 1,2 & 1,58362492 \\
\hline 2000 & 1 & 1,7 & 4,60897843 \\
\hline 3000 & 1 & 2,2 & 6,84845362 \\
\hline 4000 & 1 & 2,8 & 8,94316063 \\
\hline 5000 & 1 & 3,3 & 10,3702788 \\
\hline 6000 & 1 & 3,8 & 11,5956719 \\
\hline 7000 & 1 & 4,4 & 12,8690535 \\
\hline 8000 & 1 & 5 & 13,9794001 \\
\hline 9000 & 1 & 5,4 & 14,6478752 \\
\hline 10000 & 1 & 5,8 & 15,2685599 \\
\hline 20000 & 1 & 9,2 & 19,2757566 \\
\hline 30000 & 1 & 10,8 & 20,6684751 \\
\hline 40000 & 1 & 11,6 & 21,2891598 \\
\hline 50000 & 1 & 12 & 21,5836249 \\
\hline 60000 & 1 & 12,4 & 21,8684337 \\
\hline 70000 & 1 & 12,8 & 22,1441994 \\
\hline 80000 & 1 & 12,8 & 22,1441994 \\
\hline 90000 & 1 & 12,8 & 22,1441994 \\
\hline 100000 & 1 & 12,8 & 22,1441994 \\
\hline 200000 & 1 & 11,2 & 20,9843605 \\
\hline 300000 & 1 & 8 & 18,0617997 \\
\hline 400000 & 1 & 5,6 & 14,9637605 \\
\hline 500000 & 1 & 4,4 & 12,8690535 \\
\hline 600000 & 1 & 3,4 & 10,6295783 \\
\hline 700000 & 1 & 2,6 & 8,29946695 \\
\hline 800000 & 1 & 2,2 & 6,84845361 \\
\hline 900000 & 1 & 1,9 & 5,57507201 \\
\hline 1000000 & 1 & 1,6 & 4,08239965 \\
\hline
\end{tabular}


Tabel 4. Kondisi 3 Bass Cut, Mid Flat, dan

Trebel Cut

\begin{tabular}{|c|c|c|c|}
\hline $\mathbf{f}(\mathrm{Hz})$ & $\mathrm{Vi}(\mathrm{V})$ & Vo (V) & $G(d B)$ \\
\hline 10 & 1 & 0,044 & $-27,1309$ \\
\hline 20 & 1 & 0,084 & $-21,5144$ \\
\hline 30 & 1 & 0,12 & $-18,4164$ \\
\hline 40 & 1 & 0,152 & $-16,3631$ \\
\hline 50 & 1 & 0,18 & $-14,8945$ \\
\hline 60 & 1 & 0,21 & $-13,5556$ \\
\hline 70 & 1 & 0,24 & $-12,3958$ \\
\hline 80 & 1 & 0,27 & $-11,3727$ \\
\hline 90 & 1 & 0,29 & $-10,7520$ \\
\hline 100 & 1 & 0,32 & $-9,8970$ \\
\hline 200 & 1 & 0,6 & $-4,4370$ \\
\hline 300 & 1 & 0,72 & $-2,8534$ \\
\hline 400 & 1 & 0,76 & $-2,3837$ \\
\hline 500 & 1 & 0,8 & $-1,9382$ \\
\hline 600 & 1 & 0,8 & $-1,9382$ \\
\hline 700 & 1 & 0,8 & $-1,9382$ \\
\hline 800 & 1 & 0,8 & $-1,9382$ \\
\hline 900 & 1 & 0,8 & $-1,9382$ \\
\hline 1000 & 1 & 0,76 & $-2,3837$ \\
\hline 2000 & 1 & 0,56 & $-5,0362$ \\
\hline 3000 & 1 & 0,46 & $-6,7448$ \\
\hline 4000 & 1 & 0,34 & $-9,3704$ \\
\hline 5000 & 1 & 0,28 & $-11,0568$ \\
\hline 6000 & 1 & 0,24 & $-12,3958$ \\
\hline 7000 & 1 & 0,22 & $-13,1515$ \\
\hline 8000 & 1 & 0,19 & $-14,4249$ \\
\hline 9000 & 1 & 0,18 & $-14,8945$ \\
\hline 10000 & 1 & 0,17 & $-15,3910$ \\
\hline 20000 & 1 & 0,112 & $-19,0156$ \\
\hline 30000 & 1 & 0,092 & $-20,7242$ \\
\hline 40000 & 1 & 0,088 & $-21,1103$ \\
\hline 50000 & 1 & 0,084 & $-21,5144$ \\
\hline 60000 & 1 & 0,084 & $-21,5144$ \\
\hline 70000 & 1 & 0,084 & $-21,5144$ \\
\hline 80000 & 1 & 0,084 & $-21,5144$ \\
\hline 90000 & 1 & 0,084 & $-21,5144$ \\
\hline 100000 & 1 & 0,08 & $-21,9382$ \\
\hline 200000 & 1 & 0,076 & $-22,3837$ \\
\hline 300000 & 1 & 0,072 & $-22,8534$ \\
\hline 400000 & 1 & 0,068 & $-23,3498$ \\
\hline 500000 & 1 & 0,068 & $-23,3498$ \\
\hline 600000 & 1 & 0,068 & $-23,3498$ \\
\hline 700000 & 1 & 0,068 & $-23,3498$ \\
\hline 800000 & 1 & 0,068 & $-23,3498$ \\
\hline 900000 & 1 & 0,068 & $-23,3498$ \\
\hline 1000000 & 1 & 0,068 & $-23,3498$ \\
\hline
\end{tabular}

Tabel 5. Kondisi 4 Bass Flat, Mid Bosst, dan Trebel Flat

\begin{tabular}{|c|c|c|c|}
\hline $\mathrm{f}(\mathrm{Hz})$ & Vi (V) & Vo $(V)$ & $G(d B)$ \\
\hline 10 & 1 & 0,42 & $-7,5350142$ \\
\hline 20 & 1 & 0,72 & $-2,8533501$ \\
\hline 30 & 1 & 0,88 & $-1,1103466$ \\
\hline 40 & 1 & 0,96 & $-0,3545753$ \\
\hline 50 & 1 & 1,04 & 0,3406668 \\
\hline 60 & 1 & 1,12 & 0,9843605 \\
\hline 70 & 1 & 1,2 & 1,5836249 \\
\hline 80 & 1 & 1,28 & 2,1441994 \\
\hline 90 & 1 & 1,32 & 2,4114786 \\
\hline 100 & 1 & 1,5 & 3,5218252 \\
\hline 200 & 1 & 2,3 & 7,2345567 \\
\hline 300 & 1 & 3 & 9,5424251 \\
\hline 400 & 1 & 3,9 & 11,821292 \\
\hline 500 & 1 & 4,8 & 13,624825 \\
\hline 600 & 1 & 5,6 & 14,963761 \\
\hline 700 & 1 & 6,6 & 16,390879 \\
\hline 800 & 1 & 7,4 & 17,384634 \\
\hline 900 & 1 & 8 & 18,0618 \\
\hline 1000 & 1 & 8,4 & 18,485586 \\
\hline 2000 & 1 & 5,4 & 14,647875 \\
\hline 3000 & 1 & 3,4 & 10,629578 \\
\hline 4000 & 1 & 2,6 & 8,299467 \\
\hline 5000 & 1 & 2,2 & 6,8484536 \\
\hline 6000 & 1 & 1,9 & 5,575072 \\
\hline 7000 & 1 & 1,7 & 4,6089784 \\
\hline 8000 & 1 & 1,6 & 4,0823997 \\
\hline 9000 & 1 & 1,5 & 3,5218252 \\
\hline 10000 & 1 & 1,4 & 2,9225607 \\
\hline 20000 & 1 & 1,12 & 0,9843605 \\
\hline 30000 & 1 & 1,04 & 0,3406668 \\
\hline 40000 & 1 & 1 & 0 \\
\hline 50000 & 1 & 1 & 0 \\
\hline 60000 & 1 & 1 & 0 \\
\hline 70000 & 1 & 1 & 0 \\
\hline 80000 & 1 & 1 & 0 \\
\hline 90000 & 1 & 1 & 0 \\
\hline 100000 & 1 & 1 & 0 \\
\hline 200000 & 1 & 1 & 0 \\
\hline 300000 & 1 & 1 & 0 \\
\hline 400000 & 1 & 1 & 0 \\
\hline 500000 & 1 & 1 & 0 \\
\hline 600000 & 1 & 0,96 & $-0,3545753$ \\
\hline 700000 & 1 & 0,92 & $-0,7242435$ \\
\hline 800000 & 1 & 0,92 & $-0,7242435$ \\
\hline 900000 & 1 & 0,88 & $-1,1103466$ \\
\hline 1000000 & 1 & 0,84 & $-1,5144143$ \\
\hline
\end{tabular}


Tabel 6. Kondisi 5 Bass Flat, Mid Bosst, dan Trebel Flat

\begin{tabular}{|c|c|c|c|}
\hline $\mathbf{f}(\mathbf{H z})$ & Vi (V) & Vo (V) & $G(d B)$ \\
\hline 10 & 1 & 0,38 & $-8,4043281$ \\
\hline 20 & 1 & 0,64 & $-3,8764005$ \\
\hline 30 & 1 & 0,72 & $-2,8533501$ \\
\hline 40 & 1 & 0,74 & $-2,6153656$ \\
\hline 50 & 1 & 0,72 & $-2,8533501$ \\
\hline 60 & 1 & 0,7 & $-3,0980392$ \\
\hline 70 & 1 & 0,66 & $-3,6091213$ \\
\hline 80 & 1 & 0,64 & $-3,8764005$ \\
\hline 90 & 1 & 0,6 & $-4,436975$ \\
\hline 100 & 1 & 0,58 & $-4,7314401$ \\
\hline 200 & 1 & 0,38 & $-8,4043281$ \\
\hline 300 & 1 & 0,32 & $-9,8970004$ \\
\hline 400 & 1 & 0,28 & $-11,056839$ \\
\hline 500 & 1 & 0,22 & $-13,151546$ \\
\hline 600 & 1 & 0,18 & $-14,89455$ \\
\hline 700 & 1 & 0,132 & $-17,588521$ \\
\hline 800 & 1 & 0,116 & $-18,71084$ \\
\hline 900 & 1 & 0,108 & $-19,331525$ \\
\hline 1000 & 1 & 0,108 & $-19,331525$ \\
\hline 2000 & 1 & 0,18 & $-14,89455$ \\
\hline 3000 & 1 & 0,27 & $-11,372725$ \\
\hline 4000 & 1 & 0,36 & $-8,87395$ \\
\hline 5000 & 1 & 0,44 & $-7,1309465$ \\
\hline 6000 & 1 & 0,5 & $-6,0205999$ \\
\hline 7000 & 1 & 0,56 & $-5,0362395$ \\
\hline 8000 & 1 & 0,6 & $-4,436975$ \\
\hline 9000 & 1 & 0,64 & $-3,8764005$ \\
\hline 10000 & 1 & 0,78 & $-2,1581079$ \\
\hline 20000 & 1 & 0,88 & $-1,1103466$ \\
\hline 30000 & 1 & 0,8 & $-1,9382003$ \\
\hline 40000 & 1 & 0,96 & $-0,3545753$ \\
\hline 50000 & 1 & 0,96 & $-0,3545753$ \\
\hline 60000 & 1 & 0,96 & $-0,3545753$ \\
\hline 70000 & 1 & 0,96 & $-0,3545753$ \\
\hline 80000 & 1 & 0,96 & $-0,3545753$ \\
\hline 90000 & 1 & 0,96 & $-0,3545753$ \\
\hline 100000 & 1 & 0,96 & $-0,3545753$ \\
\hline 200000 & 1 & 0,96 & $-0,3545753$ \\
\hline 300000 & 1 & 0,96 & $-0,3545753$ \\
\hline 400000 & 1 & 0,96 & $-0,3545753$ \\
\hline 500000 & 1 & 0,96 & $-0,3545753$ \\
\hline 600000 & 1 & 0,96 & $-0,3545753$ \\
\hline 700000 & 1 & 0,96 & $-0,3545753$ \\
\hline 800000 & 1 & 0,92 & $-0,7242435$ \\
\hline 900000 & 1 & 0,88 & $-1,1103466$ \\
\hline 1000000 & 1 & 0,88 & $-1,1103466$ \\
\hline
\end{tabular}

\section{c. Poweramp Kelas AB}

Dari percobaan poweramp kelas $\mathrm{AB}$ daya rendah dengan menggunakan sepasang transistor BD 139 dan BD 140 diperoleh data seperti berikut :

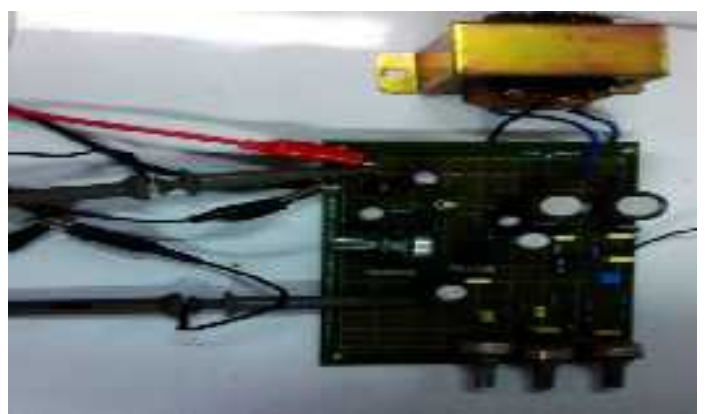

Gambar 12. Pengujian Rangkaian Poweramp Kelas $\mathrm{AB}$

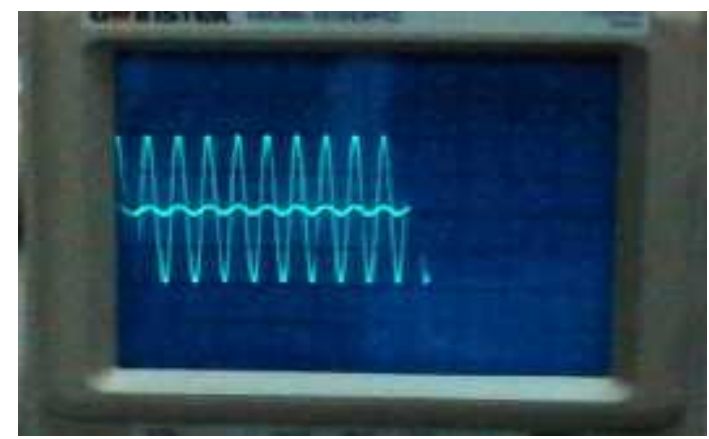

Gambar 13. Hasil Pengujian Power AMP Kelas Ab Untuk Chanel 1 Dan Chanel 2 Tidak Di Graundkan

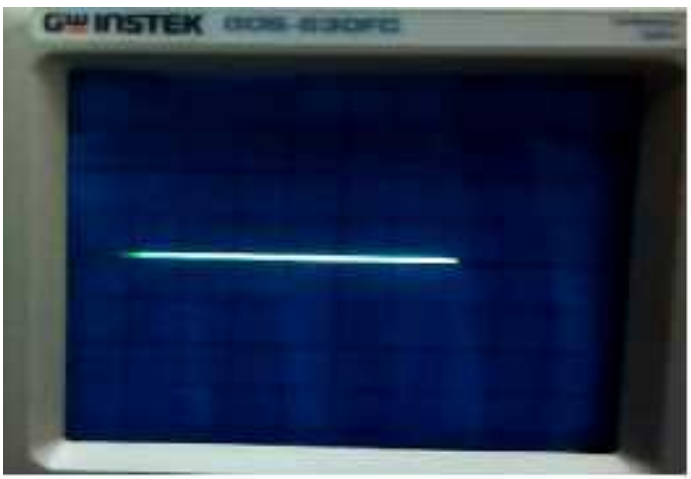

Gambar 14. Hasil pengujian Power AMP Saat Chanel 1 Dan Chanel 2 Di Groundkan

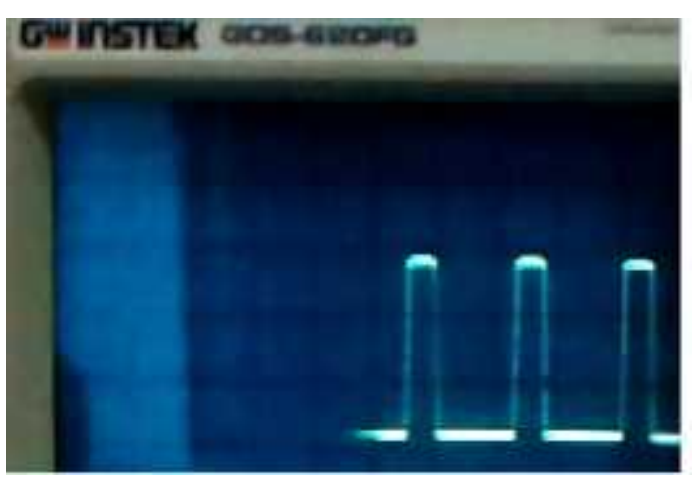

Gambar 15. Hasil pengujian Power AMP Saat Chanel 1 dan Chanel 2 di Groundkan 
Tabel 7. Besar Penguatan dengan Frekuensi Bervariasi dari $10 \mathrm{~Hz}$ sampai dengan $100 \mathrm{k} \mathrm{Hz}$

\begin{tabular}{|c|c|c|c|c|}
\hline f (log) & $\begin{array}{l}\text { Frekuensi } \\
(\mathrm{Hz})\end{array}$ & $\begin{array}{c}\mathrm{Vi} \\
\text { (Volt) }\end{array}$ & $\begin{array}{c}\text { Vo } \\
\text { (Volt) }\end{array}$ & $\mathrm{G}(\mathrm{dB})$ \\
\hline 1 & 10 & 0.36 & 6 & 24.4370 \\
\hline 1.30103 & 20 & 0.36 & 6 & 24.4370 \\
\hline 1.477121 & 30 & 0.36 & 6 & 24.4370 \\
\hline 1.60206 & 40 & 0.36 & 6 & 24.4370 \\
\hline 1.69897 & 50 & 0.36 & 6 & 24.4370 \\
\hline 1.778151 & 60 & 0.36 & 6 & 24.4370 \\
\hline 1.845098 & 70 & 0.36 & 6 & 24.4370 \\
\hline 1.90309 & 80 & 0.36 & 6 & 24.4370 \\
\hline 1.954243 & 90 & 0.36 & 6 & 24.4370 \\
\hline 2 & 100 & 0.36 & 6 & 24.4370 \\
\hline 2.30103 & 200 & 0.36 & 6 & 24.4370 \\
\hline 2.477121 & 300 & 0.36 & 6 & 24.4370 \\
\hline 2.60206 & 400 & 0.36 & 6 & 24.4370 \\
\hline 2.69897 & 500 & 0.36 & 6 & 24.4370 \\
\hline 2.778151 & 600 & 0.36 & 6 & 24.4370 \\
\hline 2.845098 & 700 & 0.36 & 6 & 24.4370 \\
\hline 2.90309 & 800 & 0.36 & 6 & 24.4370 \\
\hline 2.954243 & 900 & 0.36 & 6 & 24.4370 \\
\hline 3 & 1000 & 0.36 & 6 & 24.4370 \\
\hline 3.30103 & 2000 & 0.36 & 6 & 24.4370 \\
\hline 3.477121 & 3000 & 0.36 & 6 & 24.4370 \\
\hline 3.60206 & 4000 & 0.36 & 6 & 24.4370 \\
\hline 3.69897 & 5000 & 0.36 & 6 & 24.4370 \\
\hline 3.778151 & 6000 & 0.36 & 6 & 24.4370 \\
\hline 3.845098 & 7000 & 0.36 & 6 & 24.4370 \\
\hline 3.90309 & 8000 & 0.36 & 6 & 24.4370 \\
\hline 3.954243 & 9000 & 0.36 & 6 & 24.4370 \\
\hline 4 & 10000 & 0.36 & 6 & 24.4370 \\
\hline 4.30103 & 20000 & 0.36 & 6 & 24.4370 \\
\hline 4.477121 & 30000 & 0.36 & 6 & 24.4370 \\
\hline 4.60206 & 40000 & 0.36 & 6 & 24.4370 \\
\hline 4.69897 & 50000 & 0.36 & 6 & 24.4370 \\
\hline 4.778151 & 60000 & 0.36 & 6 & 24.4370 \\
\hline 4.845098 & 70000 & 0.36 & 6 & 24.4370 \\
\hline 4.90309 & 80000 & 0.36 & 6 & 24.4370 \\
\hline 4.954243 & 90000 & 0.36 & 6 & 24.4370 \\
\hline 5 & 100000 & 0.36 & 6 & 24.4370 \\
\hline 5.30103 & 200000 & 0.36 & 6 & 24.4370 \\
\hline 5.477121 & 300000 & 0.36 & 6 & 24.4370 \\
\hline 5.60206 & 400000 & 0.36 & 5.8 & 24.1425 \\
\hline 5.69897 & 500000 & 0.36 & 5.7 & 23.9914 \\
\hline 5.778151 & 600000 & 0.36 & 5.6 & 23.8377 \\
\hline
\end{tabular}

\begin{tabular}{llccc}
5.845098 & 700000 & 0.36 & 5.3 & 23.3595 \\
5.90309 & 800000 & 0.36 & 5 & 22.8534 \\
5.954243 & 900000 & 0.36 & 4.8 & 22.4988 \\
6 & 1000000 & 0.36 & 4.6 & 22.1291 \\
\hline
\end{tabular}

\section{d. Pengujian Rangkaian Audio dengan Hp}

Setelah semua rangkaian diuji dan diambil data maka dilakukanlah pengujian secara kesuluruhan dengan menggunakan Hp dan dicek tone kontrol apakah rangkaian berfungsi dengan baik dengan menghubungkan $\mathrm{Hp}$ ke rangkaian dan mengatur bass, mid, dan trebel pada kondisi cut sampai dengan boost.

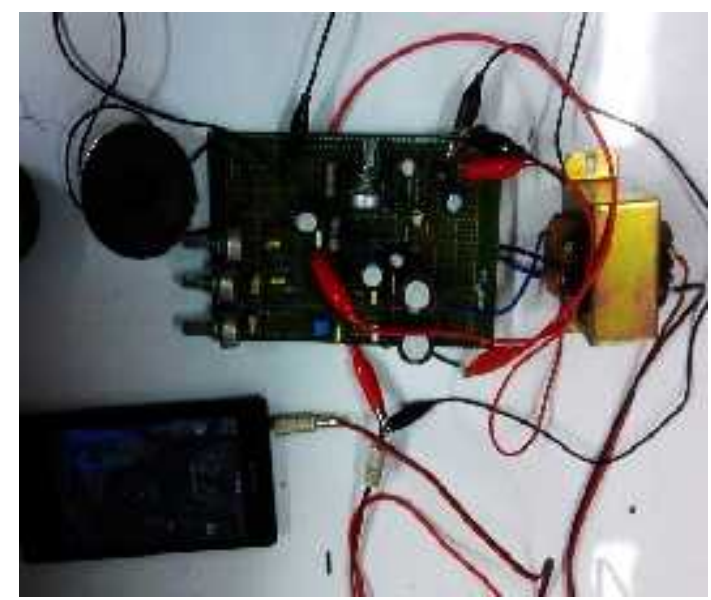

Gambar 16. Pengujian Rangkaian Audio menggunakan HP

\section{Pengolahan Data dan Analisis \\ a. Pengolahan Data \\ 1. Catu Daya (Power Supply)}

Adapun data dari table 1 dapat dibentuk seperti pada gambar 17 seperti dibawah ini :

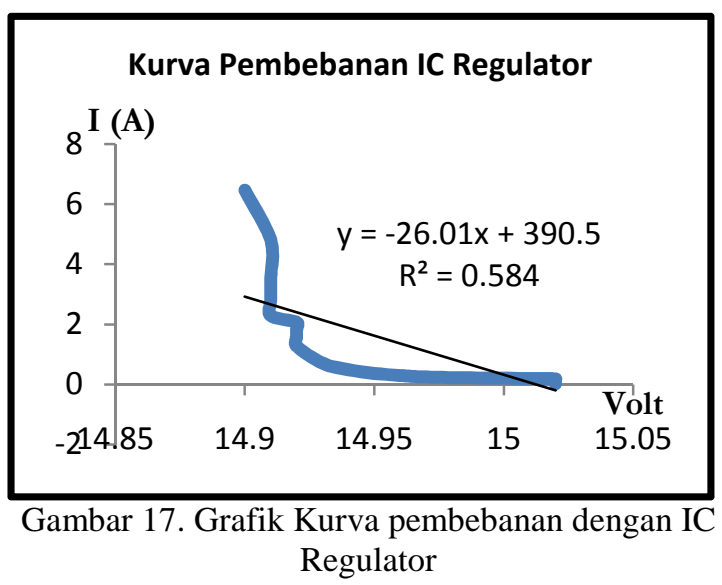




\section{Tone Control}

Adapun data dari tabel 2 sampai tabel 6 dapat dibentuk seperti pada gambar 18 seperti dibawah ini :

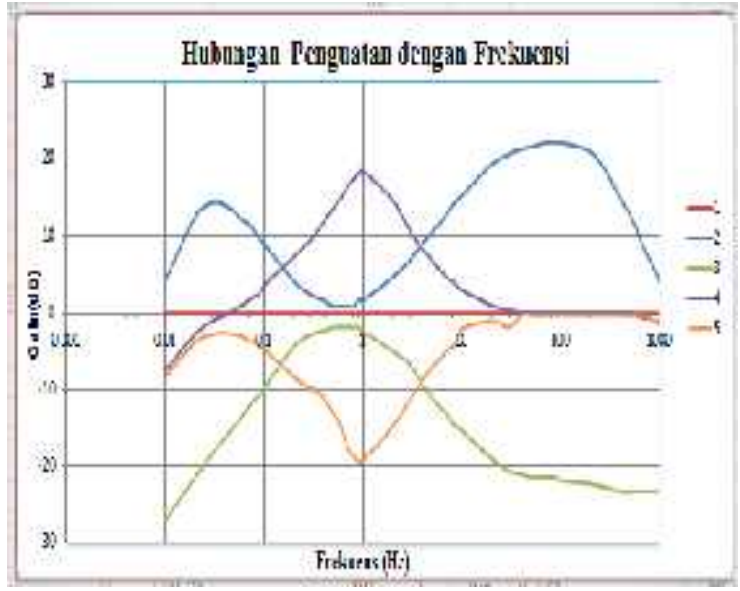

Gambar 18. Grafik Kurva hubungan penguatan dengan Frekuensi

\section{Poweramp Kelas AB}

Adapun data dari tabel 7 untuk penguatan dapat dibuat grafik seperti pada gambar seperti pada gambar 19 dan gambar 20.

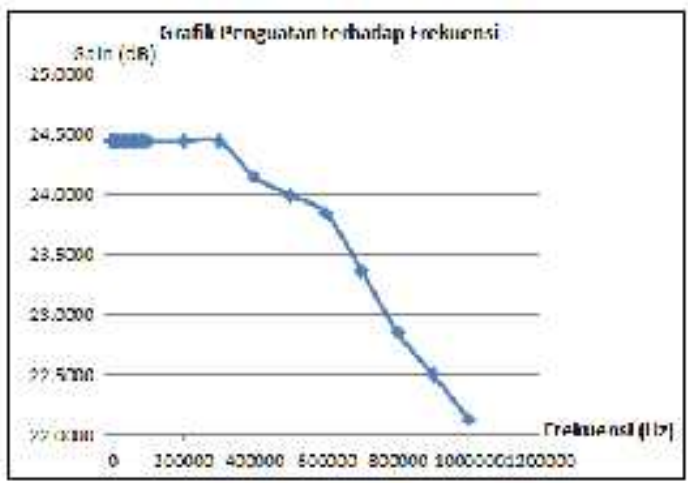

Gambar 19. Grafik Gain terhadap Frekuaensi

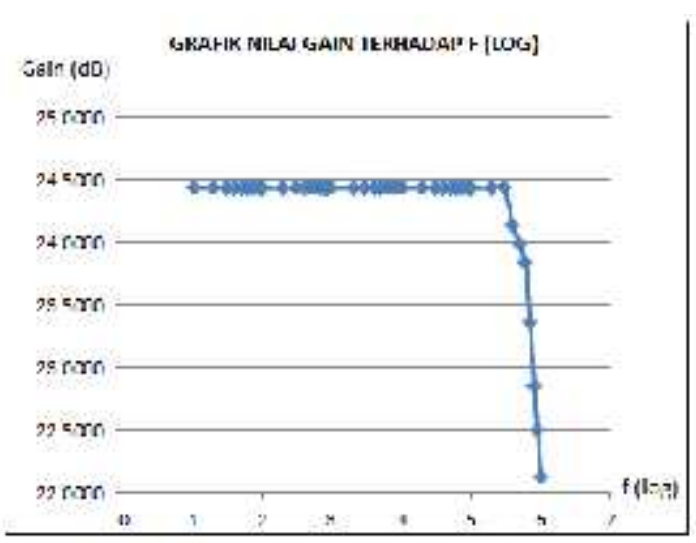

Gambar 20. Grafik Gain terhadap Frekuaensi(log)

\section{b. Analisis}

\section{Catu Daya (Power Supply)}

Tegangan keluaran yang dihasilkan oleh rangkaian dengan dengan menggunakan IC 7815 dan IC 7915 sebesar \pm 15 Volt. Berdasarkan data praktikum yang kita peroleh adalah nilai tegangan keluaran positif maka yang terukur sebagai keluaran selama positif adalah pada keluaran IC 7815 ( $\mathrm{Vcc}+$ ) dengan slope kurva pembebanan adalah $-26,015$

\section{Tone Control}

Rangkaian 3-Band Tone Control dengan Buffer Op-amp TL082 menggunakan konsep filter aktif baxandall dengan penguat berupa Opamp IC tipe TL082. Rangkaian tone control ini memiliki 3 tone pengaturan nada yaitu kontrol nada Bass, Midrange dan Treble. Rangkaian tone control 3 nada ini bekerja dengan sumber tegangan simetris \pm 15 volt.

Rangkaian penguat depan dibangun dengan penguat operasional Op-amp IC TL082 dengan penguatan 1 kali dan pada Bagian filter aktif baxandall untuk mengatur level penguatan atau pelemahan sinyal audio untuk 3 nada yaitu nada bass, midrange dan treble menggunakan jaring filter baxandall dengan penguat tegangan berupa Op-amp IC TL082.

\section{Poweramp Kelas AB}

Rangkaian Amplifier Kelas AB daya kecil dengan pasangan transistor BD139 - BD140 terjadi penguatan sebesar 16,67 dengan $G$ sebesar. Pada saat chanel 1 sebagai input dan chanel 2 sebagai output pada saat digroundkan maka posisi pada osiloskop pada satu garis yang sama seperti pada gambar 14 itu menandakan bahwa rangkaian siap dipasangkan dengan speaker dan pada saat amplitudo diputar pada signal generator dan pada frekuensi terus 
diubah semakin besar maka akan diperoleh signal terpotong seperti pada gambar 15.

Secara keseluruhan penguatan terjadi dihasilkan rasio dari $22 \mathrm{k}$ dan 1 k. Daya disipasi timbul yang menyebabkan panas padapasangan transistor BD 139 dan BD 140. Secara teori nilai efisiensi daya pada kelas $\mathrm{AB}$ yaitu sekitar 60\% dan 40\% sisanya terbuang menjadi panas.

\section{Kesimpulan}

Rangkaian audio menggunakan beberapa komponen telah berhasil dibuat untuk memanipulasi sinyal input dari hp sehingga nilai bass, mid, dan trebelnya bisa diatur menggunakan tapis lolos rendah dan tinggi sehingga dapat dibedakan dari speaker saat bass, mid, dan trebel diubah-ubah.

\section{Saran}

Sebaiknya pada saat melakukan penelitian jaga keselamatan untuk diri praktikan, alat, dan bahan. Setelah dilakukan percobaan ini maka penelitian ini dapat digunakan sebagai modul praktikum pada mata kuliah basic elektrik sehingga mahasiswa dapat mengenal dan mengaplikasikan komponen elektronika.

\section{Daftar Pustaka}

[1] Kusuma, Sastra Wijaya, 2013. Diktat Elektronika 1, Depok : Fisika FPMIPA UI

[2] Sutrisno, 1986, Elektronika Teori dan Penerapannya, ITB, Hal 2-34.

[3] http://www.zen22142.zen.co.uk/Circuits/ Audio/2wamp.html.

[4] Zaki, 2008. Cara Mudah Belajar Merangkai Elektronika Dasar, Cetakan Kedua, Yogyakarta : Absolut

[5] http://curious-giant.blogspot.co.id/2009 /12/catu-daya-power-supply.html 